\title{
The Influence of Greek Literature and Culture in the Naim Frasheri’s Poem "O Eros”
}

\author{
Blerina Harizaj (Moja) \\ Academy of Albanological Studies, Tirane, Albania
}

\begin{abstract}
This article focused on the influence that culture and ancient Greek literature had on the lyrical poem "O Eros" ("Love”), a poem by the poet of the Albanian national renaissance, Naim Fresheri. This poem written in the Greek language speaks about love and the big importance that philosophy, history, and the ancient Greek literature had in his life. The poem was published for the first time in Istanbul 1895 and its part of the phase when he wrote in the foreign languages. From the culture and Greek literature, Naim Frasheri borrowed culture, philosophy, history and Greek mythology representatives (figures), topics, ideas and even motifs. He used them for poetical, philosophical, and historical purposes. It's worth mentioning that the evocation of the ancient Greek world in his poetical works gave a lot of values to his experience as a creator. In his poem “O Eros” he addresses to love, and the absolute beauty, incarnated in the figures of Greek goddess like: Kaliope, Aphrodite, Artemis, Demetria and Urania etc. In his meditative road trip the poet to discover the mysteries of the universe and they will accompany him till the divine wayward, in the amazing residency of God. There where the power of thinking melts, the mysteries get widespread and because of God the entire universe it's alive. The love for the poet beyond the limits of humanity, it's something divine, the embodiment of God himself. It is love that brings it closer to the internal truth, that God is the source of life, love and universe. The message that the poem convey, "Love”, it's a divine message as well as universal, that claims that life without no love has no sense and that is this feeling that keeps alive not only humanity but even the world. In this work I will focus mainly on style, figurative system, Greek mythological figures and also the way, the poet artistically conceptualize the work. The method that it's going to be used is that of comparison referring the terminology of the scholar (researcher) Itamar Zohar. In conclusion, we notice that the notion of the interference brings to us another point of view regarding to Naim's work, the point of view of the ancient poetical Greek tradition.
\end{abstract}

Keywords: Naim, Frasheri, Greek literature, Eros, goddess

\section{Introduction}

In the history of its development, the Albanian literature as other world literatures, has been open to relationships with other literary systems. Albanian literature as a peripheral literature (developing) borrowed from these source systems, literary figures, mythological, historical, patterns, themes and types of poetry, and has made them part of itself, always preserving its original identity. This kind of phenomenon, the exchange between

Blerina Harizaj (Moja), Ph.D. Candidate, the Department of Literature, Academy of Albanological Studies. 
different literature experiences, we will call interference. Because of this I will refer to the Israeli scholar, Itamar Zohar who says: “

Literatures are always in interferential relationship, and with interference he means a relationship between literatures, according to a X literature A(source literature)might be source of direct or indirect borrowing for another literature B (Target literature). (Itamar Even-Zohar, 1990, p. 54)

The most typical poet it's the Albanian poet Naim Frasher, in his poetical work, we find vestiges of Greco-Roman ancient literature, oriental and also that of European.

According to the scholar Rexhep Qose: "From all foreign literature, of all countries and all times, Naim Frasheri knows the best and appreciates most the Greek and roman ancient literature and the Persian literature” (Rexhep Qose, 1989, p. 35). He had a deep admiration for the ancient culture of our neighbors that had brought incomparable services to the European culture. Without any doubt, the extensive knowledge of culture, history and literature of ancient Greek and Roman were learnt during his high school education "Zosimea” Ioannina. Knowledge and study of these languages, will make possible that the poet Frashëri read in their own languages, the most popular works of Greek literature, Roman and European. Even write in these languages, as are two of his works in the Greek language, "O Eros" and "real desire of the Albanians". This justifies even what Zohar will mention in his study, "The channels through which literary contacts occur, causing the migration of different elements. According to him are; when literature source is directly from its language, and the second case when recognized through translation” (Itamar Even-Zohar, 1990, p. 54). The contact that Naimi had with literature, culture and Greek history was straight forward, and that as a result of recognition of the profound Greek, and reading the works of ancient Greek authors, like: Homer, Sophocles, Euripides, Aeschylus, etc., in their original language. If the poem "The True Desire of Albanians" ("o alithis pothos ton skypetaron")—writes researcher Qose-Naim writes it into Greek with the purpose to convey to the Greek public to recognize the struggle of the Albanian people for freedom and independence, another poem "Love" ("O Eros") will be written and will be published in Greek even to show how Greek culture was important in his life; and if the first poem shows his interest to influence political opinion Greek the second poem shows his connection with Greek culture, in reality the love he felt for ancient traditions of literary, philosophical and ethical Greek. Whereas another scholar Jorgo Bulo quotes, "Love” (“O Eros”) is a poem about love written in Greek, (as well as the real desire of Albanians), designed in the style of school Phanariote poetry Greek.

Naimi as an intellectual and one founder of literature and national culture, has studied Greek antiquity with certain motives to find support in that culture, that would ensure the realization of his human vision. It worth mentioning that the influence that the greek literature in Naim's work, shouldn't be interpreted as an imitation from his part, even though the scholar Dhimiter Shuteriqi would say that he was pasioned by Homer, whom he will copy or adjust in Albanian later on. ${ }^{1}$

In fact, here we are dealing more with assimilation than with imitation, and the second word, it's convenient in the analyze that we are going to do to the Work of Naim Frasheri "O Eros". In the history of the theory of literature the influence is known as a positive Category, when showed as assimilation and as a negative category it is imitation. On the other side, the phenomenon of assimilation closely connected with the necessity that a developing literature has. The selection of the elements (poetic models, literary figures, genres, etc.) is done in

${ }^{1}$ Historia e letërsisë shqipe, për shkolla të mesme Enti i teksteve dhe i mjeteve mësimore i KSAK, Prishtinë, 1974, p. 1938. 
accordance with literary interests and the structure of the target literature.

"Items do not transplant mechanically from literature source to the target literature, but are the needs that determine and lead the line" (Itamar Even-Zohar, 1978, pp. 51-52) "This confirms what Naimi did to write an erotic poetry like that of on the Greek language," “O Eros” is based on mythology or Greek literature. We must say that the poetical imagination of Naimi in this work burnt from the Greek mythology, in which the most important mythological figures of the ancient Greek world, flow in the meditativo-cosmic journey of the poet. It was the 18 century, during the revolution of the philosophical illumination when the Greek myth was made a source of inspiration. But in the end of the century, Romanticism showed a big enthusiasm for every Greek thing, especially for mythology. An enthusiasm like that about Greek mythology would appear also from the Albanian Romantic Naim Frasheri, who followed the steps of the other European romantics

\section{The Influence of Greek Literature and Mythology in the Poem “O Eros”}

“O Eros”, it’s a lyrical poem made of 8 songs and 300 verses. It was published in Kostandinopoje 1895, designed in the style of the Greek Phanariote school of poetry. And written in the Greek language. According to Robert Elsye in this poem he expressed the relation with the Greek culture” (Robert Elsie, 1997, p. 175). It was his Greek friend Zoras, who pushed Naim write such a work. Demetrius Shuteriqi monograph devoted to Naimi, would mention this fact by saying, "a Greek friend who appreciated especially Naim because he used in this way the Greek language, reaching the height of poetry distinguished by its very broad classic, he wished to him to awake the lyrical wires. Like it’s now acknowledged Naim at the Love cycle ("O Eros”) successfully proved the soft lyricism under the influence of classics” (Dhimiter Shuteriqi, 1982, p. 164). Another indication that shows that naim's objective was to write a work in Greek, is the letter that addresses Mr. Karolidhis, representative of the periodical "Qiriksit” who came to Istanbul in 1885. Here’s how the poet Frashëri says, "wishing him great prosperity to the muses, once again we express our joy hoping that will soon adorn beat and Greek Parnassus with a bouquet full of aroma and beauty” (Laurent Bica, 1990, p. 121). Whereas according to the scholar Jorgo Bulo, “The Love poem differs from that of Beauty, not only because it's thought an entire one but also for all the figurative system. the artistical concept, poetical tradition, which refers, and all the other characteristics that are related to the reader addressed” (Jorgo Bulo, 1999, p. 125). If we start from the aspect of style and composition, the poet speaks like the poet of Iliada and Odise,Homer, and this can be seen in the beginning of the poem, who evokes the Goddess full of grace, beautiful and with a sweet voice, that sings to love, the most noble feeling, with which fills the wounded spirit of the poet. The Goddess doesn't have a real name, but in general she embodies the absolute and the divine beauty, to the poem "O Eros" of Naimi, is the same Goddess who we can find to "Iliad" of Homer, who sings not for the love but for the Achile's grudge.

këndo, hyjneshë mërinë e Akil Pelidit që shumë hidhërime e Kobe akejve u solli. (Homeri, 1979, p.1)

Merrja këngës me zë të ëmbël, o hyjneshë hireplotë, si një vash’ e re, kur shpirti edhe zemra po ia thotë/ himn këndoji dashurisë edhe zanave perri; eja falja zemrës sime ato këngë që di ti/ kendoji ndjenjës më fisnike që na bën të dhembshëruar; është e bukur dhe buron nga burim i shenjtëruar.

sing with your sweet voice

you goddess full of grace

like a young lady 
when your spirit and your heart its ready

sing a hymn to love and perry fairies

come and give to my heart the songs you know

sing to the noble feeling that makes us more compassionate

its beautiful and it springs from the sainted spring

Sing, goddess the anger of Peleu's son Achilleus and its devastion, which put pains thousandfold upon the Archaians. (Naim Frashëri, 1978, p. 233)

To this liric poem, the poet sings to the beauty and the love taking them into another dimension, in that of divinity. Through the poetical imagination, beauty and love moves into the heavenly space, in which the poet meets the ancient Greek godesses, as Afërdita, Artemisa, Demetra, Plutoni etc., he does not give a real figure, a real concept neither for love as well as for beauty. Love and the object of love itself to Naimi is considered more as an element of fantasy rather than of the heart, is considered more as an idea, a notion, a concept, an abstraction, more than a simple human being and a real body (Bajram Qerimi, 2000, p. 184). The world which is evoked in this work is that of Greek mythology,which gives to the poetry the name of an elite poetry and of high style (Jorgo Bulo, 1999, p. 291). The love lyric cycles, “O Eros” is considered as a meditative-cosmic journey of the poet through the universe, which have something in common, love. As the ancient greek mythology is considered as a source of narrations about love in general, he borrows important divine figures, who gives a clear message that life means nothing without love. "Life without love does not have neither taste nor joy; the world is malevolent and does not attract my soul. (Naim Frashëri, 1978, p. 243)” Since the myth about the union of the earth and the sky as a shell is always opened for vivacity and an exhaustable life, and since the myth of Eros, Pshyche, Orpheus, Euridce, Adam and Eve and a lot of other myths, it seems that there is something in common; the emotion of love has an enermous power absolutely dominant in the world and the life of the human beings and it offers continuity and infinity of the human gender. At the same time it is an insidious power of cohesion and of the balance in the whole universe of the human being and the men (Ali Aliu, 1990, p. 291).

So that is why the poet ask the Godess to throw her arrows of love to him, and the poet reverently and willingly wants to stay under their control. "Throw those immortal arrows, my dear godess ,throw your highness because they are sweet as the sugar and honey (Naim Frashëri, 1978, p. 233). What is visible in the poet's mind is that there is no place for the reason and the reason toward love is nothing. Love is the flame, is the fire and the joy to the human beings. Is that what has attracted the poet's heart/is that what have won the poet's heart. "love attracts me, when she comes closer ,and at the moment it makes me addicted, it lights my heart and my soul up" (Naim Frashëri, 1978, p. 234). What can we always find in most of the sources and alternatives is that there we can find the cultivated conflict (and we find it to the greek mythology). But how can people keep this fire and this happiness forever and at the same time, not to be under the control of an insidious voice, is the voice out of the control of the curiosity and of the mind. 
In to his cosmic journey Naim find himself close to Aferdita ${ }^{2}$ Besides of me stands Afërdita with her willowy stature and her sweet cheekbones and from her locks which covers her shoulders,flows the beauty and the happiness in the lamented heart spreads my pains. ${ }^{3}$ To Artemisa; As I see Artemisa full of grace coming toward me I can feel in my heart a new joy and through the beautiful forest as the flames dance. Part of his heart becomes her tenderness and joy who cheers it up with her beautiful colour which suits perfectly to her body and her white shoulders are covered by her gold hair. To Apolon; ${ }^{4}$ Apolon, through his rays full of life which brighten from the sky, brings with him, the spring that God makes the earth becomes as a new one and the flowers of the sky begins to bloom up, as a gift. The nature is filled full of joy and of divine cheerfulness ; so the soul and the heart of the poet is filled full of happiness. To Demetra, Pluton, Tetides, Urania, the symbols of astronomy in the Greek mythology. The poet who sings to love is mostly inspired from Eros the Goddess of love. As he sees what happended, Eros himself gives order and share every secret. In the archaic Greek poetry, the power of love the measures from his kindness which comes from the inside world, fascinates, our hearts and gives us peace.

The secret charm of love ,which is a concrete element of the human being, but also of the Goddess is part of Eros. As referring to the antique history of the Encyclopedy. Eros was the the Greek God of love, very keen on love, physical desires and passion. He does not think a lot, he chooses his target and the hit right to the heart, confusing in this case the feelings, or as Hesiod says he "weakens the arms and the mind". Eros is a young boy with a crone in his head, especially decorated by roses which are connected close to the God. ${ }^{5}$ In the poetry of Naim, Eros is considered as a symbol of the univsersal love rather than as a Goddess who effects the erotic feelings (sexual feelings). Eros goes close to her amazing beauty in her golden bed gets in and sleep,my mind is far away, and then goes with her too. Even though in this line, Eros seems to be more as a God who is more passionate rather than as an embodiement of the universal love; this scenery is more a borrowing that the poet takes from the Greek archaic poetry and both of them, the elements of the bed and that of sleeping in the bed are used in a metaphorical form, just to show the relation, the connection where love physically consumed (Claude

\footnotetext{
${ }^{2}$ In the Greek mythology,Aferdita is the symbol of love and beauty, the Goddess of joy, who try to cheer everyone; the people and the Goddesses. She was the Goddess who loved the laughter. There were no joy and there were no love without her. In the Homeric poem Aferdita expressed clearly that beauty comes from the instinct and from the general feelings. But through the Homeric writings of the archaic origin and we can see also her identification to the morning beauty and the morning star.

There must be underlined that in the poetry "o Eros" of Naim the beauty and the refreshed nature is related to the beauty of the Albanian girl. This is embodied in the beauty of Aferdita with her willowy posture and her locks over the shoulders, her sweet cheekbones etc. The poet does this for a certain reason to identify, the beauty of the Albanian woman in that of the Greece Goddess Aferdita.

The beauty of whom makes the poet younger and at the highlighting to her beauty of the God.

3 Artemisa is the lover of forest and the wild hunter in the mountains. She was the owner of the wild thing which is considered as a strange job for a woman. She was the protector of the youth everywhere. In the Greek mythology she is considered as the sister of Apolon and she had effects toward the people and the nature also she is identified to the light of the moon and that's why she is called Lightened Feba.

Her gold color of hair is identified to the light of the moon which symbolizes her. In the poem of Naimi we can see her transformation of her wild side as a men's hunter and as a denier of their love. She is lovely, beautiful and through her arrows she cheers poet's heart and from the arrows of death they become the arrows of life, cheering up the heart of the poet filling it full with love.

${ }^{4}$ Apolonius was the God who personified the light and the positivity toward the people and also the light of the sun. He is a beautiful figure in the Greek poetry, the head musician who entertains Olimpus, who play in her gold lyra, he could also play to his silver arches, he was the God of the arches able to hit from the distance. Cult of Apolonius is related to the ceremony of cry, lamented ceremony in autumn and the ceremony of happiness in spring. It is not related to the death and renaissance but it is related to the leave and return of the Goddess of Light. Naim has borrowed the figure of Apolonius to his poetry "O Eros" and his coming back is related to the symbol of joy in the spring and the poet's happiness.

${ }^{5}$ Eros, An ancient history encyclopedia www.ancient.eu
} 
Calame, 1992, p. 29).

To Naim, love is not only considered as an erotic desire or as a simple passion but it is shown as a love who goes over the the limits of the earth, it is transcendental, it is divine and at this point begins the whole the universe. Even though it is shown in different forms in that of the ancient God as a beautiful girl (as the daughter of the sky) who leads Naim into an imaginative world and also in that of a friend who conscolates the soul of the poet but at last she is the personification of the Goddess. According to Jorg Bulo "the pantheist "the motif of the combination of the infinity, of the human being and of God who is the the sense of love, of the human being and the infinity of the world, in this poem is considered philosophic-poetic motif and through them are elaborated the approaches for the life and the universe mistery as a kind of wisdom of the God" (Jorgo Bulo, 1999, p. 127). Even though in the first point of view, this poem talks about love, but deeply it treats the philosophic cases that elaborates the mistery of infinity and of life in general. He looks love as the main element to go close to the divine truth, to the discover of the universal misteries and goes up into the conclusion that the world is infinite and part of it is the human being too. According to Jorgo Bulos: "what makes a love poem give a universal message is not because it is written in one of the important universal languages, but because it has affirmed the universal truths and the universal feelings” (Jorgo Bulo, 1999, p. 127).

\section{Conclusion}

"O Eros", it's a lyric poem and give a message that love it's a divine message as well as universal, that claims that life without no love has no sense and that is this feeling that keeps alive not only humanity but even the world. In his meditative road trip the poet Naim Frasheri to discover the mysteries of the universe, all gods of Olympus will accompany him till the divine wayward, in the amazing residency of God. There where the power of thinking melts, the mysteries get widespread and because of God the entire universe it's alive. The love for the poet beyond the limits of humanity, it's something divine, the embodiment of God himself. This is a mystic dimension of love for our poet Naim Frasheri.

\section{References}

Aliu, A. (1990). Kërkime (Research).Tiranë..

Bica, L. (1990). Naimi në Kostandinopojë (Naim in Constantinople) (Vol. 1). Tiranë: The Crystal University.

Bulo, J. (1999). Tipologjia e lirikës së Naim Frashërit (The typology of Naim Frasher's lyrics). Tirane: Science.

Calame, C. (1992). The poetics of eros in ancient greece (The poetics of eros in ancient Greece). New Jersey: Princeton University Press.

Elsie, R. (1997). Historia e letërsisë shqiptare (History of Albanian Literature). Peja: Dukagjini, Tirane.

Frashëri, N. (1978). O Eros (Works 2). Pristina, Kosovo, Rebirth.

Homeri, I. (1979). Tiranë.

Qerimi, B. (2000). Poetika e Naim Frashërit (Poetry of Naim Frashëri), Tiranë: Toena.

Qose, R. (1989). Great message; Monograph for Naim Frasher's creativity. Tirane: Naim Frasheri.

Shuteriqi, D., \& Frasheri, N. (1982). Jeta dhe Vepra (Life and Works), Tiranë.

Zohar, I. (1978). Papers in historical poetics (Papers in historical poetics). The Porter Institute for Poetics and Semiotics, Tel Aviv University.

Zohar, I. (1990). Polysystem studiues (Polysystem studies). Poetics Today, Poetics Today, International Journal of Theory and Analysis of Literature and Communication, 11(1), 268. 